Review Article

\title{
Resource Domestication: An Introduction to Biodiversity and Wildlife in Agriculture
}

\author{
Benjamin E. Uchola \\ Faculty of Agriculture, Federal University, Dutsin-ma, Nigeria \\ Email address: \\ buchola@fudutsinma.edu.ng
}

\section{To cite this article:}

Benjamin E. Uchola. Resource Domestication: An Introduction to Biodiversity and Wildlife in Agriculture. American Journal of Agriculture and Forestry. Vol. 4, No. 2, 2016, pp. 23-29. doi: 10.11648/j.ajaf.20160402.13

Received: March 17, 2016; Accepted: March 28, 2016; Published: April 15, 2016

\begin{abstract}
Biodiversity and Wildlife are relatively recent concepts in Agriculture. However, the meaning of each concept remains to be clearly distinguished from similar concept in Natural Resource Conservation. The concepts of Biodiversity and Wildlife in Agriculture may be better understood when explored from the perspective of Resource Domestication. Relocation of a resource from its natural habitat into human-controlled environments represents an initial phase in the process of domestication. The final phase of Resource Domestication entails selection of desired production traits in established populations through breeding programs. A more complex relationship emerges in the course of transforming a wild plant into a crop or a wild animal into a livestock. The new relationship between a resource and its domestic form served as the framework for understanding Biodiversity and Wildlife in Agriculture.
\end{abstract}

Keywords: Agriculture, Biodiversity, Domestication, Wildlife

\section{Introduction}

Resource Domestication is a complex interaction between humans and a valued organism. It involves the relocation of a resource from its natural habitat to artificial environments as demonstrated in the domestication of oil palm (Elaeis guineensis) [1-3], rubber (Hevea brasiliensis) [4, 5], common carp (Cyprinus carpio) [6, 7] and Japanese quail (Coturnix japanicus) [8, 9]. Domestication also entails artificial selection of preferred traits as revealed in oil palm yield improvement exercises [10-12], in the development of saponin-free quinoa seeds (Chenopodium quinoa) $[13,14]$ and selection of higher body weights in Japanese quail $[15,16]$. Knowledge of Resource Domestication often provides satisfactory answers to a number of very important questions; questions such as those concerning the relationship between native Amazonian rubber trees and their plantation-grown counterpart $[4,5]$ or the differences in gonad maturation of wild African catfish (Clarias gariepinus) and their domestic form $[17,18]$.

The impact of Resource Domestication extends beyond its initial motivation. On the one hand, relocation of a resource into human-controlled environments was an expression of a desire to protect its dwindling supply occasioned by fluctuations in climatic conditions and expansion in local human populations [19-21]. On the other hand, artificial selection of traits explores the production potentials of a resource that is made visible through variations in individuals of the same population $[10,13,14,15]$. The combined effect of these aspects of domestication is a transformation of primitive resources into highly productive cultivated plants or domestic animals. However, the impact of domestication also involves the evolution of new terms as a cultivated plant is referred to as a "crop" and a domestic animal a "livestock" after their partial or complete transformation [22, 23].

The use of terms such as "biodiversity" and "wildlife" is not uncommon in the field of agriculture. Wild plants are used in crop breeding programs [24-26], some wild animals are considered as livestock of the future while others have been identified as wild progenitors of modern livestock [27-37]. However, the current concept of Biodiversity or Wildlife does not sufficiently reflect the unique attribute of agriculture as a system that develops crops from wild plants and livestock from wild animals [22, 23]. More so, similar concepts in 
Natural Resource Conservation accommodate undomesticated plants, flesh-eating birds and dangerous mammals which are not related to any crop or livestock [38, 39]. These broad concepts of Biodiversity and Wildlife blur the distinction that exists between conservation of natural resources and the development of crops or livestock through the process of domestication. It is, therefore, a necessity to understand the meaning of Biodiversity and Wildlife within the context of Resource Domestication in Agriculture.

\section{Plants, Animals and Resources}

Biotic components play important roles in processes that sustain the environment. Generally, plants serve as habitat for organisms, trap energy needed in an ecosystem but more importantly satisfy certain needs of society [22]. In the same way, animals are known to improve soil properties, aid pollination of flowers and dispersal of seeds. However, it is their utility value as adjudged by society that makes each one of them a resource [23]. But, a resource may exist only in a particular ecological zone or region. For instance, oil palm grows naturally in the rainforest of Africa, species of potato in the Andean region of South America and macadamia in Australian rainforest [1, 40, 41]. Likewise, species of wild cattle are endemic to parts of Asia, wild goat to Indian sub continent and wild sheep to Eurasia [42].

Resources seldom express their full production potential in their natural habitats. They often respond to interferences from extreme climatic conditions and biotic stress by manifesting slow growth, inconsistent fruiting pattern and low productivity [43-45]. For instance, a species of macadamia tree requires nearly two decades of growth to prepare for fruiting activities while the African bush mango grows for over a decade before the onset of maturity [46, 47]. Even more, production of fruits are often characterised by inconsistency and low yield in both cases. Like plant resources, animal resources such as wild Japanese quail and African catfish often display several attributes including late maturation and seasonal reproduction as responses to changes in environmental factors $[9,17]$

The productivity of a resource is therefore generally low given the restrictions imposed by environmental factors. Estimate of fresh fruit bunch yield of wild and semi-wild oil palm trees range from 2 to 5 tonnes per hectare [1]. Similar low patterns of productivity characterise the yield of other plant resources such as rubber and macadamia [5, 41]. The quantity of products exploited from wild animals is equally low even though comprehensive data on the production performances between a resource and its domestic form are scarce. Nonetheless, the meat yield of red jungle fowl (JF) would have been less than those of its closest domestic relatives when the growth performance of JF $(<300 \mathrm{~g})$ is considered in relation to those of domestic chicken $(>300 \mathrm{~g})$ within the same period [48, 49]. The differences in meat yield becomes vivid by comparing the production performance of JF $(<300 \mathrm{~g})$ to those of improved breeds of chicken $(>1200 \mathrm{~g})$ within the same period $[48,50]$.
Resource exploitation has consequences for the environment. Exploitation of a resource without appropriate management has lead to a situation in which the population of some species is declining as indicated by the status of common ostrich (Struthio camelus) and wild goats (Capra aegagrus) [51]. More still, some resources are either threatened with extinction or have gone extinct as in the case of wild cattle (auroch). For these reasons, natural populations are increasingly being protected through scientific studies and establishment of National parks [32, 34, 52].

\section{Resource Domestication}

Domestication is essentially an indirect approach towards the conservation of a plant or an animal resource. It involves the introduction of a resource into human-controlled environments and afterwards selection of preferred production traits [22, 23].

Relocation of a resource and selection of its traits are the major aspects in domestication projects. Seedlings of bush mango were transferred from forest to farmlands even though the preservation of the tree on farmland is still a common practice [53]. Even more, seedlings of bush mango that were propagated using vegetative methods have been used in the establishment of field banks $[54,55]$. In cultivated fields, bush mango attains maturity in about half the number of years required by its wild counterpart and produces fruits with superior indices [47, 56]. The improved performances of field-grown bush mango indicate the plant is responding to selection and also suggest the likelihood of further improvement through selection of superior genotypes. Similarly, cane rat was transferred from its natural habitat into experimental farms for the purpose of studying its growth and reproductive performances. In the course of domestication, the cane rat gradually accepted feeds during daytime, manifest higher body weight and produced larger litter size [57-59]. More still, moderate to high heritability values for body weight and other production traits including their correlations suggest that production performance of cane rat could be improved through artificial selection $[60,61]$.

Domestication therefore facilitates better trait expression in a resource. Artificial selection improved the yield of oil palm when fresh fruit bunch yield in wild/semi-wild populations ( $<5$ tonnes/ha) is compared to that of well managed plantations $(>20$ tonnes/ha) $[1,62]$. Likewise, there are improvements in productivity of animals due to effects of domestication. The meat yield of Japanese quail increased from about $100 \mathrm{~g}$ in the earliest domesticates to about $300 \mathrm{~g}$ in modern populations $[15,16]$. Similarly, a comparison of the body weights of wild jungle fowl $(<300 \mathrm{~g})$, native chicken ecotypes $(>300 \mathrm{~g})$ and improved meat breeds of chicken $(>1200 \mathrm{~g})$ within the same period [48-50], suggest meat yield of jungle fowl was improved over three times through artificial selection. In the same way, selection for milk yield in cattle increased production several times given the yield estimate of local breed $(<900 \mathrm{~kg})$ and pure breed $(>2000 \mathrm{~kg})$ within the same period [63]. This is a trend in milk production 
of local cattle breed as increases in the degree of improvement leads to a corresponding increase in milk yield [64].

\section{Resource Domestication, Biodiversity and Wildlife in Agriculture}

The review above reveals that crops and livestock are products of Resource Domestication. Cultivated apple (Malus domestica) originated from a wild plant which is related to over 50 other Malus species [Table 1a; 65, 66]. Plantation-grown rubber, field-grown potato and cultivated rice (including their varieties/clones) are the domestic forms of wild species with each having several close relatives $[4,5$, 40, 65, 67-71]. Similarly, cultured common carp (Cyprinus carpio) is a domesticate of a wild form known to have several Cyprinus species as relatives [6, 7, 72]. Domestic goat (Capra hircus) and sheep (Ovis aries) descended from different wild progenitors but each progenitor belongs to a taxonomic group with several other species [33, 35, 36, 42]. The origin of domestic chicken (Gallus domesticus) can be traced to red jungle fowl (Gallus gallus), which shares common traits with other Gallus species [Table 1b; 30, 31, 73].

Table 1a. Selected Crops and their biodiversity (Wild flora \& Varieties/ Cultivar/ Clones).

\begin{tabular}{|c|c|c|c|}
\hline Crop & Wild progenitor & Wildflora: Minimum Estimate \& Selected Examples & $\begin{array}{l}\text { Crop Diversity; Varieties / } \\
\text { Clones: Selected Examples }\end{array}$ \\
\hline Apple & & 54 species $[65,66]$ & Several hundred cultivars [68] \\
\hline $\begin{array}{l}\text { Malus } \\
\text { domestica }\end{array}$ & Malus sieversii & 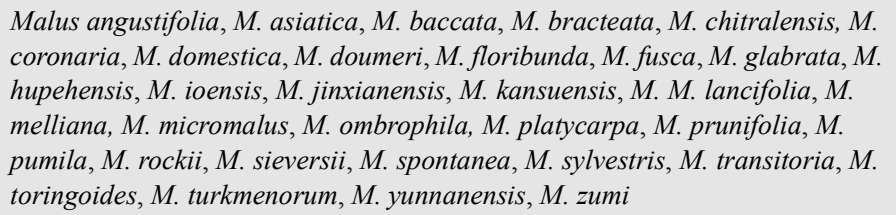 & $\begin{array}{l}\text { Malus domestica Brown, } \\
\text { Circassian, Coast, Gala, Lady, } \\
\text { Red, Landsberger Reinette, } \\
\text { Paide's Winter, Toko, Wealthy. }\end{array}$ \\
\hline Potato & & 200 species $[40,65]$ & Several varieties [69] \\
\hline $\begin{array}{l}\text { Solanum } \\
\text { tuberosum }\end{array}$ & $\begin{array}{l}\text { Several species } \\
\text { collective referred to } \\
\text { as Solanum } \\
\text { brevicaule complex. }\end{array}$ & $\begin{array}{l}\text { Solanum albornozii, S. bulbocastanum, S. bukasovii, } S . \text { burtonii, } S . \\
\text { cardiophyllum, S. chilliasense, S. commersonii, S. demissum, S. jamesii, } S . \\
\text { inutifoliolum, S. paucijugum, S. phureja, S. pinnatisectum, S. regularifolium, } S \text {. } \\
\text { stoloniferum, S. stenotomum, S. ternatum, S. tuberosum }\end{array}$ & $\begin{array}{l}\text { Solanum tuberosum Atahualpa, } \\
\text { Nicola, Russet Burbank, Tubira, } \\
\text { Vitelotte. }\end{array}$ \\
\hline Rice & & 21 species $[65,67]$ & Several hundred varieties [70] \\
\hline $\begin{array}{l}\text { Oryza } \\
\text { glaberrima } \\
\text { Oryza sativa }\end{array}$ & $\begin{array}{l}\text { O. breviligulata } O \text {. } \\
\text { nivara / } O \text {. } \\
\text { rufipogon }\end{array}$ & $\begin{array}{l}\text { Oryza australiensis, O.barthii, O. breviligulata, O. eichingeri, O. glaberrima, } \\
\text { O. grandiglumis, O. latifolia, O. longiglumis, O. longistaminata, } O . \\
\text { meridionalis, O. meyeriana, O. minuta, O. neocaledonica, } O . \text { nivara, O. } \\
\text { officinalis, O. punctata, O. ridleyi, O. rufipogon, O. sativa, O. schlechteri }\end{array}$ & $\begin{array}{l}\text { Oryza sativa Kimboka, Agora, } \\
\text { Sookha Dhan } 5 \text {, NSIC } 25 \text {, } \\
\text { Nerica. }\end{array}$ \\
\hline Rubber & & 10 species $[4,65]$ & Several clones [71] \\
\hline $\begin{array}{l}\text { Hevea } \\
\text { brasiliensis }\end{array}$ & Hevea brasiliensis & $\begin{array}{l}\text { Hevea benthamiana, } H \text {. brasiliensis, } H . \text { camargoana, } H . \text { camporum, } H \text {. } \\
\text { guianensis, } H \text {. microphylla, } H . \text { nitida, } H . \text { pauciflora, } H \text {. rigidifolia, } H . \\
\text { spruceana }\end{array}$ & $\begin{array}{l}\text { GT } 1 \text {, Tjir, PB 86, PB 260, PB } \\
\text { 312, RRII 105, RRII } 430 \text { RRIM } \\
\text { 600, RRIM 712, RRIC 100, } \\
\text { RRIC130. }\end{array}$ \\
\hline
\end{tabular}

Table 1b. Selected Livestock and their biodiversity (Wild fauna \& breeds).

\begin{tabular}{|c|c|c|c|}
\hline Livestock & Wild Progenitor & Wild Fauna: Estimate \& Examples & Livestock Diversity*: Estimate \& Selected Examples \\
\hline $\begin{array}{l}\text { Carp } \\
\text { (Common) }\end{array}$ & & 22 (6 listed) [72] & Several [7] \\
\hline $\begin{array}{l}\text { Cyprinus } \\
\text { carpio }\end{array}$ & Cyprinus carpio [6] & $\begin{array}{l}\text { Cyprinus acutidorsalis } C \text {. barbatus, } C \text {. } \\
\text { carpio, } \text { C. micristius, C. rubrofuscus, } \\
\text { C. yunnanensis }\end{array}$ & $\begin{array}{l}\text { Cyprinus carpio Feng, Germany mirror, Hebao red, Heyuan, } \\
\text { Huanghe, Jian, Lotus, Molong, Songhe, Songpu, Xingguo red, } \\
\text { Xiangyun, Ying, Yue, Scattered mirror. }\end{array}$ \\
\hline Cattle & & $5[42]$ & $112[74,75]$ \\
\hline Bos taurus & $\begin{array}{l}\text { B. p. primigenius } \\
\text { +opisthonomous }\end{array}$ & $\begin{array}{l}\text { Bos gaurus, B. javanicus, B. mutus, } B . \\
\text { primigenius, B. sauveli }\end{array}$ & $\begin{array}{l}\text { Aberdeen Angus, Ayrshire, Braford, Brahman, Brown Swiss, } \\
\text { Charolais, Chusco, Creole, Devon, Dexter, Galloway, Gascon, } \\
\text { Gelbvieh, Goudali, Guersney, Hereford, Holstein, Limousin, }\end{array}$ \\
\hline Bos indicus & B.p. nomadicus $[28,29]$ & & $\begin{array}{l}\text { Lincoln Red, Muturu, Ndama, Normande, Red Angus, Senepol, } \\
\text { Sokoto Gudali, White fulani. }\end{array}$ \\
\hline Chicken & & $4[73]$ & $101[74,75]$ \\
\hline
\end{tabular}




\begin{tabular}{|c|c|c|c|}
\hline Livestock & Wild Progenitor & Wild Fauna: Estimate \& Examples & Livestock Diversity*: Estimate \& Selected Examples \\
\hline $\begin{array}{l}\text { Gallus } \\
\text { domesticus }\end{array}$ & Gallus gallus $[30,31]$ & $\begin{array}{l}\text { Sub species of Gallus gallus bankiva, } \\
\text { Jabouillei, murghi, spadiceus } \\
\text { G. lafeyettei } \\
\text { G. sonneratii } \\
\text { G. varius }\end{array}$ & $\begin{array}{l}\text { Amrock, Australorp, Baladi Beheri, Bresse, Campine, Crevecoeur, } \\
\text { Derbyshire Redcap, Dokki, Dresdener, Faverolles, Fayoumi, } \\
\text { Gournay, Hamburgs, Hampshire, Jersey Giant, La Fleche, Minorca, } \\
\text { NewHampshire, Orloff, Orpington, Plymouth Rock, Rhodebar, } \\
\text { Sussex, Vorwerk, Warren, Wyandotte }\end{array}$ \\
\hline Goat & & $8-9[42]$ & $40[74,75]$ \\
\hline C. a. hircus & Capra aegagrus $[35,36]$ & $\begin{array}{l}\text { C. aegagrus } \\
\text { C. caucasica } \\
\text { C. cylindricornis } \\
\text { C. falconeri } \\
\text { C. ibex } \\
\text { C. nubiana } \\
\text { C. pyrenaica } \\
\text { C. sibirica } \\
\text { C. walie }\end{array}$ & $\begin{array}{l}\text { Anglo-Nubian, Angora,, Barbari, Bengal, Berber, Boer, Dutch Pied, } \\
\text { Gaddi, Granada, Kahalari, Kamori, Karachai, Maradi, Maure, } \\
\text { Murciana, Nigerian Dwarf, Oberhasli, Peacock Goat, Poitou, } \\
\text { Saanen, Sahelian, Somali, Toggenburg, Tswana, Verata. }\end{array}$ \\
\hline Pig & & & $33[74,75]$ \\
\hline $\begin{array}{l}\text { Sus s. } \\
\text { domesticus }\end{array}$ & Sus scrofa [37] & Sus scrofa $[73]$ & $\begin{array}{l}\text { Alentejana, American Berkshire, Berkshire, Chester White, } \\
\text { Dalland, Duroc, Ghori, Haitian, Jersey Red, Lacombe, Large Black, } \\
\text { Large White, Mangalitsa, Meishan, North Caucasus, Pelon, } \\
\text { Pietrain, Saddleback, Seghers, Siska, Spotted, Tamworth, } \\
\text { Turopolje, Welsh, Wessex Saddleback. }\end{array}$ \\
\hline Sheep & & $6[42]$ & $100[74,75]$ \\
\hline Ovis aries & Ovis orientalis [33] & $\begin{array}{l}\text { O. ammon } \\
\text { O. canadensis } \\
\text { O. dalli } \\
\text { O. orientalis } \\
\text { O. nivicola } \\
\text { O. vignei } \\
\end{array}$ & $\begin{array}{l}\text { Australian Merino, Awassi, Blue Texel, Bond, British Milksheep, } \\
\text { Chios, Coopworth, Corriedale, Devon Longwool, Dormer, Dorper, } \\
\text { Dorset, Dorset Down, Drysdale, Finnsheep, North Ronaldsay, } \\
\text { Quessant, Pool Merino, Polwarth, Polypay, Portland, Santa Cruz, } \\
\text { Texel, Van Rooy, West African Dwarf, Zwartbles. }\end{array}$ \\
\hline
\end{tabular}

*Trans-boundary Breeds/Hybrids

The development of a crop or livestock establishes new relationships. Cultivated rice as a special grain-producing plant plays the role of a food crop while other species of rice remain mere plants of an ecosystem. More still, cultivated rice responds to series of further selection for disease resistance and other traits resulting in the development of several varieties (Table 1a). The movement of rice from a mere plant or plant resource to a crop with varieties represents a process of rice development [22]. This development process establishes a new and complex relationship which consists of the wild progenitor of rice as well as other oryza species, earliest cultivated rice and its varieties. Put differently, cultivated rice and its varieties are the most advanced forms of rice while other Oryza species are wild flora, wild relatives or less developed forms. Cultivated rice, its varieties and wild flora when summed up represents the biodiversity of rice (Rice Biodiversity). In the same way, the biodiversity of other crops would be the sum of their earliest cultivated forms, varieties/clones and wild flora (Table 1a). Like crops, domestic chicken is an animal kept for a purpose while other Gallus species are mere birds or bird resource of an ecosystem. The development of domestic chicken establishes its wild fauna as less developed forms while domestic chicken and its breeds are the most advanced in terms of productivity (Table 1b). Therefore, the constituents of chicken biodiversity are the earliest form of domestic chicken, its breeds and wild fauna. Similarly, the biodiversity of other livestock such as cattle, sheep and pig would be the sum of their individual wild fauna, earliest domestic form and breeds.

From Resource Domestication perspective, biodiversity is a specific concept that excludes all botanical entities that are not related to any particular crop or zoological entities that are unrelated to a known livestock. Accordingly, the biodiversity of rice excludes other members of the grass family (Poaceae or Gramineae). As a result, grasses such as spear grass (Imperata cylindrica) and other similar plants that are not directly related to any crop may not be categorised as part of Biodiversity in Agriculture. Likewise, the biodiversity of cattle excludes all members of the family (Bovinae) except its wild fauna, domestic form and breeds. In other words, cattle-like animals like African buffalo (Syncerus caffer) which fatally attack humans or American bison (Bison bison) whose domestication has largely been unsuccessful, do not belong to Cattle Biodiversity. These organisms and others like African grey parrot (Psittacus erithacus) and mountain gorilla (Gorilla beringei) are considered part of biodiversity by Natural 
Resource Conservation-based Organisations [38, 39]. Interestingly, a Resource Domestication-based concept of biodiversity alters the concept of Wildlife to that which revolves around wild flora of crops and wild fauna of livestock.

\section{Conclusion}

The use, of basic terms like crop or livestock, is an implicit acknowledgement of Resource Domestication in Agriculture. Development of crops and livestock from wild resources reveals that Biodiversity and Wildlife have their roots in Resource Domestication. However, Biodiversity and Wildlife are distinct concepts in Agriculture. Biodiversity expresses the sum of different development levels of a particular crop or livestock while Wildlife is a collective term for either wild flora of crops, wild fauna of livestock or wild forms of both crops and livestock.

\section{References}

[1] A. C. Zeven, The semi-wild oil palm and its industry in Africa. Agricultural Research Report, No. 687,178 p. 1967.

[2] A. C. Zeven, "The partial and complete domestication of oil palm (Elaeis guineensis)". Economic Botany Vol. 26, pp. 274 279. 1972.

[3] R. H. V. Corley, B. S. Gary and S. K. Ng, "Productivity of the oil palm (Elaeis guineensis Jacq.) in Malaysia". Experimental Agriculture Vol. 7, pp. 129-136, 1971a.

[4] R. E. Schultes, "A brief taxonomic view of the genus Hevea. Malaysian Rubber" Research and Development Board, Kuala Lumpur. Monograph no. 14, 1990.

[5] R. E. Schultes, "The domestication of the rubber tree: economic and sociological implications". Amer J Econ Soc Vol. 52 (4), pp. 479-485. 1993.

[6] E. K. Balon, "Origin and domestication of the wild carp, Cyprinus carpio: from Roman gourmets to the swimming flowers". Aquaculture Vol.129, pp. 3-48. 1995.

[7] Z. Jeney and Z. Jian, "Use and exchange of aquatic resources relevant for food and aquaculture: common carp (Cyprinus carpio L.)" Reviews in Aquaculture Vol.1, pp.163-173. 2009.

[8] Kerr H. W. Quailology: The domestication, propagation, care and treatment of wild quail in confinement. Little Sioux, Iowa, U. S. A: The Taxiderm Company. 1903.

[9] G. B. Chang, X. P. Liu, H. Chang, G. H. Chen, W. M. Zhao, D. J. Ji, R. Chen, Y. R. Qin, X. K. Shi and G. S. Hu "Behavior differentiation between wild japanese quail and domestic quail”. Poultry Science Vol.88, pp. 1137-1142. 2009.

[10] R. H. V. Corley, J. J. Hardon and G. Y. Tan, "Analysis of growth of the oil palm (Elaeis guineesis Jacq) I. Estimation of growth parameters and applicaton in breeding”. Euphytica Vol. 20, pp. 304-315. $1971 \mathrm{~b}$.

[11] J. J Hardon; R. H. V Corley and C. H. Lee. Breeding and selecting the oil palm. In: Abott, A. J and Atkin, R. K (Eds). Improving Vegetatively Propagated Crops. Academic Press Ltd, London. Pp 63-68. 1987.
[12] H. Limburg and H. D. "Mastebroek Breeding high yielding lines of Chenopodium quinoa Willd. with saponin free seed". Proceedings of COST-Workshop., 22-24/2 1996, European Commission EUR 17473/KVL, Copenhagen Copenhagen: KVL, pp. 103-114. 1996.

[13] H. D. Mastebroek, E. N. Van Loo and O. Dolstra, "Combining ability for seed yield traits of Chenopodium quinoa breeding lines”. Euphytica Vol. 125(3), pp. 427-432, 2002.

[14] K. E. Nestor, W. L. Bacon and A. L. Lambio, "Divergent selection for body weight and yolk precursor in Coturnix coturnix japonica. 1. Selection response". Poultry Science Vol. 61, pp. 12-17. 1982.

[15] H. L. Marks. Long-term selection for body weight in japanese quail under different environments. Poultry Science Vol. 75, pp. 1198-1203. 1996.

[16] N. B. Anthony, K. E. Nestor and H. L. Marks. Short-term selection for four-week body weight in japanese quail. Poultry Science Vol.75, pp. 1192-1197. 1996.

[17] D. O. Owiti and S. Dadzie, "Maturity, fecundity and the effect of reduced rainfall on the spawning rhythm of a siluroidcatfish, Clarias mossambicus (Peters)". Aquaculture and Fisheries Management Vol. 20, pp. 355-368. 1989.

[18] C. J. J. Richter, W. J. A. R. Viveen, E. H. Eding, M. Sukkel, A. J. Rothuis, M. F. P. M. Van Hoof, F. C. J. Van Den Berg et al, The significance of photoperiodicity, water temperature and an inherent endogenous rhythm for the production of viable eggs by the African catfish, Clarias gariepinus, kept in subtropical ponds in Israel and under Israeli and Dutch hatchery conditions. Aquaculture Vol. 63, pp. 169-185. 1987.

[19] M. A. Blumler, "Independent inventionism and recent genetic evidence on plant domestication". Econ. Bot. Vol.46, pp. 98-111. 1992.

[20] J. Diamond, "Evolution, consequences and future of plant and animal domestication". Nature. Vol.418, pp. 700-707. 2002.

[21] F. Salamini, H. Özkan, A. Brandolini, R. Schäfer-Pregl and W. Martin, "Genetics and geography of wild cereal domestication in the near east. Nature Review Genetics Vol. 3, pp. 429-441. 2002.

[22] B. E. Uchola, "Agriculture: From a development perspective to Plant Resource Domestication". Amer. J. Agric. Forest. Vol. 3(4), pp. 127-134. 2015a.

[23] B. E. Uchola, "Agriculture: From a development perspective to Animal Resource Domestication. J. Res. Agric. Anim. Sci. Vol. 3(2), pp. 05-12. 2015b.

[24] J. G. Hawkes, "Significance of wild species and primitive forms for potato breeding". Euphytica. Vol.7, pp. 257-270. 1958.

[25] D. S. Brar, R. Dalmacio, R. Elloran, R. Aggarwal, R. Angeles and G. S. Khush, "Gene transfer and molecular characterization of introgression from wild Oryza species into rice". Khush G. S (Ed.) Rice Genetics Ill. Proceedings of the Third International Rice Genetics Symposium. Manila, Philipines. International Rice Research Institute, Manila-Philippines. pp. 477-486. 1996.

[26] R. Hajjar and T. Hodgkin, "The use of wild relatives in crop improvement: a survey of developments over the last 20 years". Euphytica, Vol.156: pp. 1-13. 2007. 
[27] NRC. Microlivestock: Little-Known Small Animals with a Promising Economic Future. (Washington, DC. National Academy Press 1991). 448p. 1991.

[28] R. T. Loftus, D. E. MacHugh, D. G. Bradley, P. M. Sharp and P. Cunningham. Evidence for two independent domestication of cattle. Proceedings of the National Academy of Sciences USA, Vol. 91(7), pp. 2757-2761. 1994.

[29] D. G. Bradley, D. E. MacHugh, P. Cunningham and R. T. Loftus, "Mitochondrial DNA diversity and the origins of African and European cattle". Proceedings of the National Academy of Sciences USA, 93(10), pp. 5131-5135. 1996.

[30] A. Fumihito, T. Miyake, M. Takada, R. Shingu, T. Endo, T. Gojobori, N. Kondo and S. Ohno, "Monophyletic origin and unique dispersal patterns of domestic fowls". Proceedings of the National Academy of Sciences USA. Vol. 93(13), pp. 6792-6795. 1996.

[31] H. Sawai, H. L. Kim, K. Kuno, S. Suzuki, H. Gotoh, M. Takada, N. Takahata, Y. Satta, and F. Akishinonomiya, "The origin and genetic variation of domestic chickens with special reference to Jungle fowls Gallus g. gallus and G. varius". PLOS ONE 5(5): 2010 .

[32] R. A. Fuller, J. P. Carroll and P. J. K. McGowan (eds.). Partridges, Quails, Francolins, Snowcocks, Guineafowl, and Turkeys. Status Survey and Conservation Action Plan 2000-2004. (Gland, Switzerland; Cambridge, UK: IUCN, and Reading, UK: the World Pheasant Association, 2000). vii +63 pp.

[33] S. Hiendleder, K. Mainz, Y. Plante and H. Lewalski, "Analysis of mitochondrial DNA indicates that the domestic sheep are derived from two different ancestral maternal sources: no evidences for the contribution from urial and argali sheep". J. Hered., Vol. 89, pp. 113-120. 1998.

[34] Shackleton, D. M (Ed). Status and distribution of Caprinae by region. In: Wild Sheep and Goats and their Relatives. Status Survey and Conservation Action Plan for Caprinae. Shackleton, D. M. (ed.) and the IUCN/SSC Caprinae Specialist Group. IUCN, Gland, Switzerland and Cambridge, UK. 390 + vii pp. 1997.

[35] G. L. Luikart, L. Gielly, L. Excoffier, J-D. Vigne, J. Bouvet and P. Taberlet, "Multiple maternal origins and weak phylogeographic structure in domestic goats". Proceedings of the National Academy of Sciences USA, Vol. 98(10). pp. 5927 5930. 2001

[36] M. B. Joshi, P. K. Rout, A. K. Mandal, C. Tyler-Smith, L. Singh and K. Thangaray, "Phylogeography and origins of Indian domestic goats". Mol. Biol. Evol., Vol. 21(3), 454-462. 2004.

[37] E. Guiffra, J. M. H. Kijas, V. Amarger, Ö. Calborg, J. T. Jeon and L. Andersson, "The origin of the domestic pigs: independent domestication and subsequent introgression". Genetics, Vol. 154(4), pp. 1785-1791. 2000.

[38] IUCN. The IUCN Red List of Threatened Species. International Union for the Conservation of Nature. www.iucnredlist.org.

[39] WWF. Endangered Species Conservation. World Wildlife Fund www.worldwildlife.org.

[40] R. J. Hijmans and D. M. Spooner, "Geographic distribution of wild potato species". Amer. J Bot. Vol. 88(11), pp. 2101-2112, 2001 .
[41] J. M. Neal, C. M. Hardner and C. L. Gross, "Population demography and fecundity do not decline with habitat fragmentation in the rainforest tree Macadamia integrifolia (Proteaceae)". Biol. Cons., Vol.143, pp. 2591-2600. 2010.

[42] The IUCN Red List of Threatened Species. Bos, Capra and Ovis. www.iucnredlist.org. Downloaded on 23 February 2016.

[43] C. M. Herrera, P. Jordano, J. Guitian and A. Traveset, "Annual variability in seed production by woody plants and the masting concept: Reassessment of principles and relationship to pollination and seed dispersal". Amer. Naturalist Vol. 154, pp. 576- 594. 1988.

[44] D. Kelly and V. L. Sork, "Mast seeding in perennial plants: Why, how, where". Annual Rev. Ecol. Syst. Vol. 33, pp. 427447, 2002.

[45] E. E. Goldschmidt, "The evolution of fruit tree productivity: A review”. Econ Bot. Vol. 67(1), pp. 51-62, 2013.

[46] C. M. Hardner, C. Peace, A. J. Lowe, J. Neal, P. Pisanu, M. Powell, A. Schmidt, C. Spain and K. Williams, "Genetic Resource and Domestication of Macadamia". Horticultural Reviews Vol. 35, pp. 1-125, 2009.

[47] D. O. Ladipo, J. M. Fondoun and N. Ganga, "Domestication of the bush mango (Irvingia spp.): some exploitable intraspecific variations in west and central Africa", in Domestication and commercialization of non-timber tree products for Agro-forestry. FAO Tech Paper, No. 9. FAO, Rome. Pp. 193205,1996

[48] I. Zulkifli, H. S. Iman Rahayi, A. R. Alimon, M. K. Vidyadaran and S. A. Babjee, "Responses of choice-fed red jungle fowl and commercial broiler chickens offered a completed diet, corn and soybean". Asian-Australasian J. An. Sci. Vol. 14(12), pp. 1758-17562. 2001.

[49] J. A Oluyemi, D. F. Adene and G. O. laboye, "Comparison of Nigeria indigenous fowl with White Rock under conditions of disease and nutritional stress". Trop. Anim. Hlth Prod. Vol. 11, pp. 199-202. 1979.

[50] B. D. Binda, I. A. Yousif, K. M. Elamin and H. E. Eltayeb, "A comparison of performance among exotic meat strains and local chicken ecotypes under Sudan conditions". Int. J. Poul. Sci. Vol. 11(8), pp. 500-504. 2012.

[51] The IUCN Red List of Threatened Species. Struthio camelus, Capra aegagrus. www.iucnredlist.org. Downloaded on 23 February 2016.

[52] FAO, DFSC, IPGRI. Forest genetic resources conservation and management. Vol. 2: In managed natural forests and protected areas (in situ). International Plant Genetic Resources Institute, Rome, Italy. $98 \mathrm{pp}+.2001$.

[53] E. T. Ayuk, B. Duguma, S. Franzel, J. Kengue, M. Mollet, T. Tiki-Manga and P. Zenkeng "Uses, management and economic potential of Irvingia gabonensis in the humid lowlands of Cameroon”. Forest Ecol Mgt, Vol. 113, pp. 1-9. 1999.

[54] P. N. Shiembo, A. C. Newton and R. R. B. Leakey, "Vegetative propagation of Irvingia gabonensis, a West African fruit tree". Forest Ecol Mgt Vol. 87, pp. 185-192. 1996.

[55] Z. Tchoundjeu, B. Duguma, J-M. Fondoun and J. Kengue, "Strategy for the domestication of indigenous fruit trees of West Africa: case of Irvingia gabonensis in southern Cameroon". Cameroon J Biol Biochem Sci Vol. 4, pp. 21-28, 1998. 
[56] A. R. Atangana, Z. Tchoundjeu, J-M. Fondoun, E. Asaah, M. Ndoumbe and R. R. B. Leakey, "Domestication of Irvingia gabonensis: I. Phenotypic variation in fruit and kernel traits in two populations from the humid lowlands of Cameroon". Agroforestry Systems. Vol. 53, pp. 55-64, 2001.

[57] S. S. Ajayi and O. O. Tewe "Food preference and carcass composition of the grasscutter (Thryonomys swinderianus) in captivity". Afr. J. Ecol. Vol. 18 (2-3), pp. 133-140. 1980.

[58] C. H. Steir, G. A. Mensah and C. F. Gall, "Breeding of cane rats (Thrynomys swinderianus) for the production of meat". World Anim. Rev. Vol. 69, pp. 44-49. 1991.

[59] S. A. Onadeko and F. O. Amubode, "Reproductive indices and performance of captive reared grasscutters (Thryonomys swinderianus Temminck)" Nig. J. Anim. Prod. Vol. 29(1), pp. 142-149. 2002.

[60] S. Y. Annor, B. K. Ahunu, G. S. Aboagye, K. Boa-Amponsem and J. P. Cassady, "Phenotypic and genetic estimates of grasscutter production traits. 1. (Co) variance components and heritability". Glo. Adv. Res. J. Agric. Sc. Vol. 1(6), pp. 148-155. 2012a.

[61] S. Y. Annor, B. K. Ahunu, G. S. Aboagye, K. Boa-Amponsem and J. P. Cassady, "Phenotypic and genetic estimates of grasscutter production traits.2. Genetic and phenotypic correlations. Glo. Adv. Res. J. Agric. Sc. Vol. 1(6), pp. 156-162. $2012 b$.

[62] C. D. Ataga and H. A. M. Van Der Vossen "Elaeis guineensis Jacq". In: Van Der Vossen, HAM \& Mkamilo GS (eds). PROTA 14: Vegetable oils/Oléagineux. [CD-Rom]. Wageningen, Netherlands. 2007.

[63] R. I. Ogundipe and A. A. Adeoye, "Evaluation of the dairy potential of Friesian, Wadara and their crossbreds in Bauchi State". Scholarly J Agric Sc. Vol. 3(6), pp. 223-225. 2013.
[64] V. Buvanendran, M. B. Olayiwole, K. I. Protrowskiu and B. A. Oyejola, "A comparison of milk production traits in Friesian $\mathrm{X}$ White Fulani crossbred cattle". Anim prod Vol. 32, pp. 165-170. 1981.

[65] The plant list 2013. www.theplantlist.org.

[66] J. B. Phipps, K. R. Robertson, P. G. Smith, J. R. Rohrer, "A checklist of the subfamily Maloideae (Rosaceae)". Can. J. Bot. Vol. 68, pp. 2209-2269. 1990.

[67] G. S. Khush, "Origin, dispersal, cultivation and variation of rice”. Plant Molecular Biology Vol. 35, pp. 25-34, 1997.

[68] Germplasm Resources Information Network, United States Department of Agriculture. http://www.ars-grin.gov Retrieved 2015-11-01.

[69] FAO International Year of Potato, 2008. Potato varieties. http://www.fao.org/potato-2008/en/potato/varieties.html

[70] IRRI Rice varieties. Global release: 2014. irri.org

[71] Rubber Board 2002. Rubber clones. http://rubberboard.org.

[72] Froese R. and Pauly D., eds. Species of Cyprinus in FishBase. August 2011 version.

[73] The IUCN Red List of Threatened Species: Gallus and Sus. www.iucnredlist.org. Downloaded on 23 February 2016.

[74] FAO. The State of the World's Animal Genetic Resources for Food and Agriculture, Barbara Rischkowsky \& Dafydd Pilling (Ed). FAO, Rome. Pp. 31-36. 2007.

[75] FAO Domestic Animal Diversity Information System. dad.fao.org Retrieved 2016-01-28. 